\title{
Pemeriksaan Laboratorium Cystatin C Untuk Uji Fungsi Ginjal
}

\author{
Rismawati Yaswir, Afrida Maiyesi
}

\section{Abstrak}

Cystatin C merupakan protein berat molekul rendah (13kD) yang disintesis oleh semua sel berinti dan ditemukan diberbagai cairan tubuh manusia. Cystatin $\mathrm{C}$ difiltrasi bebas oleh glomerulus dan tidak disekresi, kemudian direabsorpsi tetapi mengalami katabolisme hampir lengkap oleh sel epitel tubulus proksimal ginjal, sehingga tidak ada yang kembali kedarah, dengan demikian kadarnya dalam darah menggambarkan LFG, sehingga dapat dikatakan CysC merupakan penanda endogen yang mendekati ideal.

Pemeriksaan CysC dapat dilakukan untuk menentukan kadar LFG pada neonatus, anak dan dewasa, karena Kadar CysC tidak dipengaruhi oleh usia, jenis kelamin, tinggi dan berat badan, inflamasi, massa otot, hormonal, dan ras. Pemeriksaan LFG dengan CysC tidak ada variasi diurnal seperti kreatinin, sedangkan variasi biologik lebih baik daripada kreatinin.

Penurunan ringan fungsi ginjal lebih cepat terdeteksi oleh $\mathrm{Cys} \mathrm{C}$ daripada kreatinin. Untuk menilai penurunan LFG, nilai sensitivitas, spesifisitas, dan efisiensi diagnostik CysC yang paling baik (98\%) didapatkan jika digunakan titik potong batas atas kadar $\mathrm{CysC} 1,31 \mathrm{mg} / \mathrm{l}$. Pemeriksaaan kadar CysC urine dapat dilakukan untuk mengetahui adanya disfungsi tubulus proksimal.

Pemeriksaan CysC dapat dilakukan dengan metode ELISA, PETIA dan PENIA, metode PENIA presisinya lebih baik dan rentang nilai normalnya lebih stabil. Sampel untuk pemeriksaan CysC dapat dipergunakan serum, plasma EDTA dan heparin, urine, serta mulai diteliti penggunaan sampel darah kapiler sehingga dapat digunakan pada pasien yang pengambilan darah vena sulit dilakukan seperti pada bayi dan anak.

Kata kunci: Laju filtrasi glomerulus/LFG, Cystatin C/CysC

Abstract

Cystatin $C$ is a low molecular weight (13kD) protein is synthesized by all nucleated cells and are found in various human body fluid. Cystatin $C$ is freely filtered by the renal glomerulus and not secreted, reabsorbed, but then suffered a nearly complete catabolized by proximal tubular epithelial cells, so that no one returned into the blood, thus describing GFR level in the blood, so it can be said endogenous CysC is marker close to ideal.

Serum CysC assay has been introduced as a marker of GFR in children as well as adults. Cys-C levels are independent of age, gender, height and weight, muscle mass, inflamatory condition, hormone and ras. Serum Cys $C$ also is a good marker of GFR in neonates. Measurement of GFR with CysC no diurnal variation such as creatinine, whereas the biological variation is better than creatinine.

Mild decrease in renal function detected by CysC faster than creatinine. To assess the reduction in LFG, the sensitivity, specificity, and diagnostic efficiency of the most well CysC (98\%) obtained when used above the cut off limit CysC levels of $1.31 \mathrm{mg} / \mathrm{l}$. Urine levels of $\mathrm{CysC}$ can be done to determine the presence of proximal tubular dysfunction.

Cystatin C examination can be done by ELISA, PETIA and PENIA methods. PENIA method precision is better and more stable range of normal value. Samples for the measurement of Cys $C$ can be used by serum, EDTA and heparin plasma, urine, and began to study the use of capillary blood samples that can be used in patient with difficult venous sampling as in infants and children.

Keywords: Glomerular filtation rate/GFR, Cystatin C/CysC

Affiliasi penulis : Bagian Patologi Klinik Fakultas Kedokteran Universitas Andalas Padang.

Korespondensi : Rismawati Yaswir, Bagian Patologi Klinik Fakultas Kedokteran Universitas Andalas Padang/RSUP.Dr.M.Djamil. pdspatklin pdg@yahoo.com Telp/Fax: 0751-841514

\section{Pendahuluan}

Ginjal mempertahankan komposisi cairan ekstraseluler yang menunjang fungsi semua sel tubuh. Kemampuan ginjal untuk mengatur komposisi cairan ekstraseluler merupakan fungsi per satuan waktu yang diatur oleh epitel tubulus. Untuk zat yang tidak disekresi oleh tubulus, pengaturan volumenya berhubungan dengan laju filtrasi glomerulus (LFG). Seluruh zat yang larut dalam filtrasi glomerulus dapat direabsorpsi atau disekresi oleh tubulus. ${ }^{1}$
Laju filtrasi glomerulus telah diterima secara luas sebagai indeks terbaik untuk menilai fungsi ginjal. Pengukuran LFG merupakan hal yang penting dalam pengelolaan pasien dengan penyakit ginjal. Selain untuk menilai fungsi ginjal secara umum, banyak kegunaan penting pengukuran LFG, seperti untuk mengetahui dosis obat yang tepat yang dapat dibersihkan oleh ginjal, untuk mendeteksi secara dini adanya gangguan ginjal, mencegah gangguan ginjal lebih lanjut, mengelola pasien dengan transplantasi ginjal, dan dalam penggunaan kontras media radiografik yang berpotensi nefrotoksik. Karena itu diperlukan pemeriksaan LFG yang mempunyai nilai akurasi yang tinggi. ${ }^{2,3}$

Beberapa metode telah ditemukan untuk mengukur LFG. Bersihan inulin merupakan baku emas 
untuk mengukur LFG. Beberapa waktu kemudian bersihan dari beberapa bahan radioisotop seperti Chromium 51-EDTA, Technetium 99-DTPA, lothalamate, dan lohexol (nonradioisotop) mempunyai akurasi yang mendekati sama dengan bersihan inulin. Tetapi berbagai pemeriksaan ini memerlukan waktu, tenaga dan biaya yang besar serta tidak praktis, sehingga bahan ini kurang ideal untuk aplikasi rutin atau penggunaan klinik dalam jumlah yang banyak ${ }^{4,5}$

Saat ini penanda endogen yang paling sering digunakan adalah kreatinin serum, baik sendiri maupun dikombinasikan dengan urine tampung 24 jam untuk menentukan bersihan kreatinin. Beberapa faktor dapat memengaruhi ketepatan penggunaan kreatinin untuk uji fungsi ginjal, seperti ketelitian dalam mengukur jumlah urine 24 jam, pengaruh massa otot terhadap produksi kreatinin endogen, asupan daging, aktivitas fisik, adanya sekresi kreatinin di tubulus ginjal, pengaruh obat-obatan, dan masalah analitik metode pemeriksaan kreatinin ${ }^{4.5}$

Berbagai kekurangan kreatinin membuat para ahli mengembangkan penelitian untuk mencari penanda endogen yang lebih akurat dalam mengukur LFG. Beberapa protein dengan berat molekul rendah telah diteliti sebagai penanda LFG, dan salah satunya adalah cystatin $\mathrm{C}$ (CysC) yang ditemukan diberbagai cairan tubuh manusia. Berbagai penelitian melaporkan bahwa pemeriksaan CysC serum atau plasma lebih baik dari kreatinin sebagai penanda LFG. ${ }^{6}$

Pada tinjauan pustaka ini akan dibahas mengenai CysC meliputi sejarah, fungsi fisiologis dan struktur, sintesis dan metabolisme, serta pemeriksaan laboratoriumnya untuk uji fungsi ginjal.

\section{CYSTATIN C}

\section{Pengertian}

Cystatin $\mathrm{C}$ adalah suatu protein berat molekul rendah $(13 \mathrm{kDa})$ yang disintesis oleh semua sel berinti, fungsi fisiologisnya sebagai inhibitor protease sistein. $^{4,6}$

\section{Sejarah}

Cystatin C ditemukan pertama kali pada tahun 1961 oleh Jorgen Clausen dalam cairan serebrospinal manusia dinamakan $\mathrm{Y} \operatorname{trace}\left(\mathrm{V}^{-}\right.$ CSF/cerebrospinal fluid), Butler dan Flynn pada tahun yang sama menemukannya pada urine. Tahun 1981 Barrett memperkenalkan penamaan cystatin yang termasuk kedalam kelompok inhibitor protease sistein. Cystatin C secara formal diidentifikasi tahun 1984 . $^{7,8}$

Cystatin $C$ diduga sebagai penanda baru LFG pada tahun 1979, ketika didapatkan kadar plasma CysC meningkat 13 kali lebih tinggi pada pasien hemodialisis dibandingkan orang sehat. ${ }^{9}$

Cystatin C dilaporkan pertama kali sebagai penanda LFG pada tahun 1985 oleh Simonsen et al, yang mendapatkan bahwa kadar CysC serum berkorelasi negatif kuat dengan LFG. ${ }^{7,10}$

\section{Fungsi Fisiologis dan Struktur}

Cystatin C termasuk kedalam kelompok kedua dari superfamily cystatin. Ada 11 macam superfamily cystatin dan CysC merupakan inhibitor terpenting protease sistein. ${ }^{5}$

Protease sistein adalah enzim proteolitik yang ditemukan dalam lisosom sel. Fungsi protease sistein penting dalam metabolisme normal sel, menjadi dasar untuk pergantian protein intraseluler, degradasi kolagen, dan memecah prekursor protein. ${ }^{11}$

Cystatin $C$ berfungsi sebagai pengatur aktivitas proteolitik dari protease sistein yang disekresikan atau bocor dari lisosom sel yang mati atau sel yang rusak. Keseimbangan antara protease sistein dan inhibitornya sangat penting dalam pengaturan aktivitas proteolitik pada kondisi fisiologis normal, maupun dalam degradasi protein patologis dan penyakit keganasan. ${ }^{7,11}$.

Cystatin C merupakan protein non glikosilasi dengan berat molekul $13 \mathrm{kDa}$, terdiri dari dua ikatan disulfida, 120 asam amino, disintesis sebagai sebuah preprotein (menunjukkan fungsi ekstraseluler) dengan 26-residu signal peptida dan merupakan produk gen $7,3-\mathrm{K}$ base yang ditemukan pada kromoson 20 yang dikodekan oleh gen CST3 tipe housekeeping. Preprotein ini memiliki pl (isoelektrik point) 9,3 sedangkan bentuk lainnya yang ditemukan di urine pl $7,8 .^{7.8}$

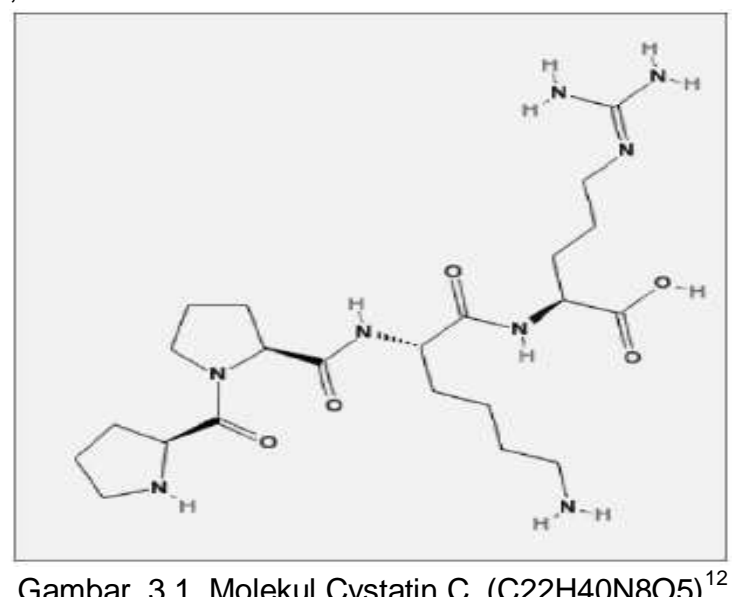

\section{Metabolisme dan sintesis}

Cystatin C disintesis secara konstan oleh semua sel berinti, dan ditemukan dengan kadar yang tinggi diberbagai cairan tubuh manusia (Tabel.1), dengan waktu paruh 2 jam, kemudian diekskresikan hanya melalui ginjal $^{7,12,13}$

Kecepatan produksi CysC relatif konstan dari umur 4 bulan sampai 70 tahun, tidak dipengaruhi oleh inflamasi, massa otot, jenis kelamin, usia, dan ras, serta komposisi tubuh. Kadar CysC tertinggi pada usia 1 hari, kemudian dengan cepat menurun selama 4 bulan pertama yang ditafsirkan sebagai akibat proses pematangan ginjal. Setelah usia 1 tahun maka kadar CysC menjadi sama dengan usia dewasa. Kadar CysC pada bayi prematur secara bermakna lebih 
meningkat dibandingkan dengan dewasa, dimana didapatkan kadar CysC antara 1,10-2,06 mg/L., 7,9

Tabel. 1 Kadar Normal Cystatin C pada Cairan Tubuh Manusia. $^{7}$

\begin{tabular}{lll}
\hline & Kadar Cystatin C & Rerata \\
& $(\mathrm{mg} / \mathrm{L})$ & \\
\hline Cairan Serebrospinal & $3,2-12,5$ & 5,8 \\
$\underline{\text { Seminal plasma }}$ & $41-62$ & 51,0 \\
$\underline{\text { Saliva }}$ & $0,36-4,8$ & 1,8 \\
$\underline{\text { Urine }}$ & $0,03-0,29$ & 0,095 \\
Air susu & $2,2-3,9$ & 3,4 \\
Cairan amnion & $0,8-1,4$ & 1,0 \\
Serum & $\sim 2,0$ & \\
Blood plasma & $0,5-1,2$ & \\
Air mata & $0,57-1,79$ & 0,96 \\
\hline
\end{tabular}

Berteli et al 1997 melaporkan bahwa setelah 48 jam kelahiran, kadar CysC akan menurun secara bermakna. Cystatin C tidak dapat melewati plasenta dan akan diproduksi sendiri oleh neonatus. Tidak ada korelasi antara kadar CysC ibu dengan neonatus seperti pada kreatinin, sehingga CysC merupakan penanda LFG yang baik untuk neonatus, dan digunakan untuk deteksi dini kelainan kongenital traktus urinarius pada neonatus. ${ }^{5,8}$.

Aktivitas CysC dapat berkurang pada keadaan inflamasi oleh protease serin, netrofil elastase. Kadar CysC rendah pada hipotiroid dan meningkat pada hipertiroid dibandingkan dengan eutiroid. Penelitian Poge et al memperlihatkan bahwa terapi kortikosteroid setelah tiga hari terapi rutin sesudah tranplantasi ginjal dan pemakaian dosis tinggi metilprednisolon untuk terapi rejeksi secara bermakna meningkatkan kadar serum CysC. Pada penelitian in vitro juga memperlihatkan terjadi peningkatan $80 \%$ sekresi CysC oleh sel HeLa setelah terpapar deksametason. Kadar CysC secara bermakna juga meningkat pada pasien asma dewasa yang mendapat terapi metilprednisolon dibandingkan dengan kontrol. ${ }^{9}$

Sebuah penelitian menyatakan bahwa terdapat hubungan bermakna antara peningkatan CysC dan progesifitas keganasan pada melanoma dan kanker kolorektal. Rerata kadar serum CysC pada pasien leukemia juga meningkat secara bermakna dibandingkan dengan kontrol. ${ }^{9}$.

\section{Cystatin C untuk Uji Fungsi Ginjal}

Karena tingginya pl maka CysC lebih bermuatan positif sewaktu berada diglomerulus, sehingga mudah melewati membran basalis yang bermuatan negatif, serta berat molekulnya yang rendah dapat difiltrasi secara bebas oleh glomerulus. Cystatin C direabsorpsi oleh tubulus proximal dan tidak disekresi, tetapi mengalami katabolisme hampir lengkap (99\%) oleh sel tubulus proksimal sehingga tidak ada yang kembali kedarah. Dengan demikian kadar CysC dalam darah mengambarkan LFG dan dapat dikatakan mendekati penanda LFG endogen yang ideal. ${ }^{2,12}$

Beberapa penelitian menunjukkan bahwa penurunan ringan fungsi ginjal lebih mudah terdeteksi oleh CysC daripada kreatinin. Coll (2000) dalam penelitiannya mendapatkan bahwa CysC serum mulai meningkat diatas nilai normal pada LFG $88 \mathrm{ml} / \mathrm{menit}$, sedangkam kreatinin serum baru mulai meningkat bila LFG sudah turun sampai $75 \mathrm{ml} /$ menit. Pada penurunan ringan fungsi ginjal (LFG 50-83ml/menit) didapatkan CysC meningkat pada $100 \%$ pasien, sedangkan kreatinin serum hanya meningkat pada $75 \%$ pasien. Newman et al pada penelitiannya terhadap 469 pasien menyimpulkan bahwa selain merupakan penanda LFG yang lebih baik daripada kreatinin serum, CysC juga merupakan penanda yang lebih sensitif terhadap perubahan kecil LFG. Pada penurunan fungsi ginjal ringan didapatkan CysC meningkat pada $71,4 \%$ pasien, sedangkan kreatinin serum hanya meningkat pada 52,45 pasien. $^{5}$

Penelitian Herget-Rosenthal et al menemukan bahwa gagal ginjal akut dideteksi 1,5 hari lebih cepat dengan serum CysC dibandingkan kreatinin. Penelitian Hojs et al 2006, mendapatkan bahwa serum CysC penanda LFG yang lebih baik dibandingkan kreatinin pada pasien yang mengalami kerusakan fungsi ginjal derajat ringan sampai sedang (CKD stadium 2-3, LFG 30-89/ml/menit/1,73m².

Penelitian Christensson et al 2004 yang meneliti 41 pasien diabetes tipe 1 dan 82 pasien tipe 2, mendapatkan bahwa serum CysC secara bermakna lebih baik dalam mendeteksi nefropati stadium awal atau ringan (LFG $\left.<80 \mathrm{~mL} / \mathrm{menit} / 1,73 \mathrm{~m}^{2}\right)$, dan tidak didapatkan perbedaan untuk mendeteksi kerusakan ginjal lanjut (LFG $\left.<60 \mathrm{~mL} / \mathrm{menit} 1,73 \mathrm{~m}^{2}\right) .{ }^{13}$.

Penelitian Bokenkamp et al 1998 menemukan bahwa kadar serum CysC tidak dipengaruhi oleh usia, tinggi dan berat badan, jenis kelamin, dan komposisi tubuh. Karena itu CysC dapat dijadikan alternatif untuk pemeriksaan LFG pada anak. $^{13}$

Kadar CysC tidak dipengaruhi oleh massa otot, karena itu CysC dapat digunakan untuk menilai fungsi ginjal pada pasien dengan kelainan yang memengaruhi kadar kreatinin, seperti anoreksia, penyakit hati, dan penyakit neuromuskuler. ${ }^{5,13}$

Keevil et al 1998 melaporkan bahwa penilaian LFG dengan CysC tidak mengenal variasi diurnal seperti kreatinin, sedangkan variasi biologik lebih baik dari kreatinin. Untuk kreatinin serum variasi inter-individual 93\% dan variasi intra-individual 7\%, sedangkan untuk CysC variasi inter-individual 25\% dan variasi intra-individual $75 \%$. Berdasarkan hal tersebut disimpulkan bahwa CysC adalah penanda yang lebih baik untuk mendeteksi gangguan fungsi ginjal dibandingkan kreatinin, tetapi kreatinin masih baik untuk mendeteksi perubahan sementara pada seseorang yang telah diketahui menderita penyakit ginjal. $^{14 .}$. 
Penelitian Galteau et al 2001 menemukan bahwa tidak ada pengaruh bermakna antara pubertas, pengunaan kontrasepsi oral, dan menopause pada kadar serum CysC. ${ }^{15}$

Penelitian Villa et al 2005 pada 51 pasien ICU didapatkan bahwa serum CysC lebih baik daripada serum kreatinin dalam mendeteksi perubahan LFG pada pasien kritis. Demikian juga penelitian oleh Le Bricon et al 2005 pada 38 pasien ICU yang mendapatkan bahwa serum CysC lebih baik daripada serum kreatinin untuk pengukuran LFG, terutama pada pasien-pasien yang diketahui penggunaan kreatinin tidak akurat seperti; obesitas dan malnutrisi. ${ }^{16}$

Penelitian krishnamurthy et al 2010 pada 20 pasien sebelum dan sesudah hemodialisis mendapatkan bahwa terjadi peningkatan kadar serum CysC sesudah dialisis, sedangkan kadar serum kreatinin mengalami penurunan, maka CysC tidak dapat digunakan untuk memonitor adekuatnya hemodialisis, namun dengan pemeriksaan CysC secara rutin pada pasien hemodialisis dapat membantu memonitor klinis pasien secara keseluruhan. ${ }^{16}$

Untuk menilai penurunan LFG, nilai sensitivitas, spesifisitas, dan efisiensi diagnostik CysC yang paling baik (98\%) didapatkan jika digunakan titik potong batas atas kadar CysC 1,31 mg/l, sedangkan jika dipakai titik potong batas atas kadar CysC yang lebih tinggi yaitu $1,58 \mathrm{mg} / \mathrm{l}$; maka didapatkan sensitivitas dan efisiensi diagnostik yang lebih rendah. Nilai sensitivitas, spesifisitas, dan efisiensi diagnostik CysC ini lebih baik dibandingkan dengan kreatinin. Efisiensi diagnostik yang paling baik (88\%) untuk kreatinin didapatkan jika digunakan titik potong batas atas kadar kreatinin $91 \mu \mathrm{mol} / \mathrm{l}$ tetapi dengan sensitivitas $74 \%$ dan spesifisitas $97 \%$. Jika titik potong batas atas kreatinin dinaikkan menjadi $114 \mu \mathrm{mol} / \mathrm{l}$, maka didapatkan efisiensi diagnostik $83 \%$, sensitivitas $53 \%$, dan spesifisitas $100 \%$ sedangkan jika titik potong batas atas kreatinin diturunkan menjadi $56 \mu \mathrm{mol} / \mathrm{l}$, maka didapatkan efisiensi diagnostik $71 \%$, sensitivitas $100 \%$, dan spesifisitas 55\% (tabel 2). ${ }^{5}$.

Tabel .2 Efisiensi Diagnostik Cystatin C dan Kreatinin Terhadap Penurunan LFG pada Titik Potong yang Berbeda. ${ }^{5}$

\begin{tabular}{|c|c|c|c|c|c|c|}
\hline & $\begin{array}{c}\text { Titik } \\
\text { Potong } \\
\%\end{array}$ & $\begin{array}{c}\text { Sensitivitas } \\
\%\end{array}$ & $\begin{array}{c}\text { Spesifisitas } \\
\%\end{array}$ & $\begin{array}{c}\text { NPP } \\
\%\end{array}$ & $\begin{array}{c}\text { NPN } \\
\%\end{array}$ & $\begin{array}{c}\text { Efisiensi } \\
\%\end{array}$ \\
\hline $\begin{array}{l}\text { Cystatin } \\
\text { (mg/L) }\end{array}$ & $\begin{array}{c}1,31 \\
1,55 \\
91\end{array}$ & $\begin{array}{c}100 \\
63 \\
74\end{array}$ & $\begin{array}{c}97 \\
100 \\
97\end{array}$ & $\begin{array}{c}95 \\
100 \\
93\end{array}$ & $\begin{array}{c}100 \\
83 \\
86\end{array}$ & $\begin{array}{l}98 \\
87 \\
88\end{array}$ \\
\hline $\begin{array}{l}\text { Kreatinin } \\
(\mu \mathrm{mol} / \mathrm{L})\end{array}$ & $\begin{array}{c}114 \\
56\end{array}$ & $\begin{array}{c}53 \\
100\end{array}$ & $\begin{array}{c}100 \\
55\end{array}$ & $\begin{array}{c}100 \\
56\end{array}$ & $\begin{array}{c}79 \\
100 \\
\end{array}$ & $\begin{array}{l}83 \\
71\end{array}$ \\
\hline
\end{tabular}

\section{Cystatin C Urine Untuk Penanda Kerusakan Tubulus Proksimal}

Cystatin C difiltrasi bebas oleh glomerulus, kemudian direabsorpsi dan dikatabolisme hampir lengkap (99\%) oleh sel tubulus proksimal. Pada kerusakan tubulus proksimal maka CysC tidak reabsorpsi sehingga diekskresikan melalui urine, maka peningkatan kadar CysC urine menjadi penanda kerusakan tubulus. Pada keadaan normal kadar CysC urine sangat rendah yakni $0,03-0,3 \mathrm{mg} / \mathrm{L}^{17}$

Penelitian Mijuskovic et al. 2007, yang membandingkan antara kadar CysC urine pada pasien disfungsi glomerulus dan tubulus dengan kontrol, didapatkan perbedaan bermakna antara keduanya, pada pasien disfungsi glomerulus didapatkan kadar CysC 0,0-0,48mg/L, sedangkan pada disfungsi tubulus $0,25-18 \mathrm{mg} / \mathrm{L}$. Penelitian yang sama oleh Conti et al. 2006, juga mendapatkan bahwa kadar CysC urine pada pasien penyakit tubulus lebih tinggi secara bermakna dengan penyakit glomerulus, juga didapatkan rerata kadar CysC yang stabil tanpa variasi sircadian. Dengan tiadanya variasi sircadian maka dapat digunakan urine sewaktu untuk kasus akut (emergensi) yang memerlukan penilaian LFG segera. ${ }^{17}$

\section{Pemeriksaan Laboratorium Cystatin C}

Pemeriksaan imunologi pertama untuk mengukur CysC ditemukan oleh Loberg dan Grubb pada tahun 1979 dengan metode enzyme-amplified single radial immunodiffusion. Metode ini mempunyai batas deteksi $30 \mu \mathrm{g} / \mathrm{L}$. Metode lainnya untuk mendeteksi CysC ditemukan beberapa tahun kemudian, berdasarkan radio, flourescent, dan enzymatic immunoassay. Batas pemeriksaan untuk metode ini adalah antara 0,13-1,9 $\mu \mathrm{g} / \mathrm{L}$ nilai referensi diidentifikasi dari laki-laki dan perempuan. ${ }^{7,8}$.

Metode awal pemeriksaan CysC ini termasuk radial immunodifusi dan enzim immunoassay, membutuhkan waktu yang lama, dan presisinya rendah. ${ }^{18}$

Metode terakhir yang ditemukan adalah automated homogeneous immunoassay menggunakan latex atau partikel polystyrene yang dilapisi dengan antibodi CysC spesifik. Ada dua versi berbeda untuk metode latex immunoassay, pertama berdasarkan metode particle-enhanced turbidimetric immunoassay(PETIA) yang ditemukan oleh KyhseAnderson et al pada tahun 1994, dan metode kedua berdasarkan nefelometri (particle-enhanced nephelometric immunoassay/PENIA) yang diperkenalkan oleh Dade Behring GmBh tahun 1997. 
Metode kedua presisinya lebih baik dari metode pertama dan interval referensinya dilaporkan lebih konsisten, sehingga metode PENIA merupakan metode terbaik untuk pemeriksaan $\mathrm{CysC}$. $^{7,8}$

Heparin dan EDTA dapat memengaruhi pemeriksaan CysC sehingga pemeriksaan lebih baik mengunakan serum daripada plasma. Pengaruh EDTA terhadap pemeriksaan CysC belum jelas, tetapi diduga berperan dalam reaksi imunoagregasi. Pengaruh heparin juga belum dapat dijelaskan. ${ }^{5}$

Penelitian Finney et al.1997, dengan metode PENIA mendapatkan bahwa tidak ada perbedaan bermakna antara kadar CysC plasma EDTA dan litium heparin, perbedaan bermakna didapatkan antara serum dan plasma tetapi kecil (3\%), plasma EDTA lebih besar menyebabkan perbedaan dibandingkan dengan litium heparin. ${ }^{5}$

Nilai normal CysC menurut NCCLS (national committee for clinical laboratory standards) adalah 0,54-1,21 $\mathrm{mg} / \mathrm{L}$, yang didapatkan dengan metode nefelometri. $^{16}$

Penelitian Kort et al. 2005, yang memeriksa kadar CysC dari sampel vena dan kapiler, memperlihatkan bahwa tidak ada perbedaan sistematik antara sampel vena dengan kapiler. Penelitian ini menunjukkan bahwa serum CysC dapat diperiksa dari darah yang didapatkan dari kapiler ujung jari. ${ }^{17}$

\section{Metode Enzyme Linked immunosorbent Assay/ELISA. ${ }^{18}$}

\section{Prinsip Pemeriksaan}

Pemeriksaan ini merupakan pemeriksaan kuantitatif secara sandwich enzyme immunoassay. Antibodi monoklonal spesifik untuk CysC sebelumnya dilapisi ke microplate. Standar dan sampel dipipet ke dalam well jika terdapat CysC maka akan diikat oleh antibodi. Setelah pencucian substansi yang tidak berikatan, sebuah enzim pengikat antibodi monoklonal spesifik/enzyme-linked monoclonal antibody spesific untuk CysC ditambahkan ke dalam well. Kemudian dilakukan lagi pencucian untuk membuang reagen antibodi-enzim yang tidak berikatan, lalu larutan substrat ditambahkan ke dalam well dan warna yang terbentuk secara proporsional menunjukkan jumlah CysC yang berikatan pada tahap awal. Pembentukan warna dihentikan dan intensitas warna diperiksa.

\section{Metode PETIA/particle-enhanced turbidimetric immunoassay. $^{19}$}

\section{Prinsip Pemeriksaan}

Cystatin C yang didapatkan dari Sampel serum atau plasma dicampur dengan anti CysC yang didapatkan dari immunopartikel. Kompleks partikel yang terbentuk akan menyerap cahaya, dan dengan turbidimetri penyerapan cahaya berhubungan dengan kadar CysC melalui interpolasi pada sebuah kurva kalibrasi standar yang ditetapkan.

\section{Sampel}

Sampel yang digunakan adalah serum atau plasma EDTA/heparin, dianjurkan menggunakan sampel segar. Sampel serum atau plasma stabil selama 14 hari pada temperatur ruangan $\left(8-25^{\circ} \mathrm{C}\right)$, selama 21 hari pada suhu $2-8^{\circ} \mathrm{C}$, dan selama 3 bulan bila disimpan pada suhu $-20^{\circ} \mathrm{C}$.

Rentang pemeriksaan untuk metode ini adalah pada kadar CysC 0,4-8,0mg/L, dan nilai normal CysC adalah 0,53-1,01mg/L.

Tidak didapatkan interferensi dengan trigliserida $12,5 \mathrm{mmol} / \mathrm{ml}$, hemoglobin $8,0 \mathrm{~g} / \mathrm{L}$, bilirubin $420 \mathrm{mg} / \mathrm{L}$, obat-obatan, serta reumatoid faktor (RF) karena antibodi dibuat dari avian (ayam).

\section{Metode PENIA/Particle-enhanced immuno- nephelometry. ${ }^{20}$}

\section{Prinsip Pemeriksaan}

Partikel Polystyrene yang dilapisi dengan antibodi CysC beraglutinasi ketika dicampur dengan sampel yang mengandung CysC. Intensitas dari cahaya yang dipancarkan/scattered light diperiksa menggunakan immunonefelometri dan tergantung pada kadar CysC dalam sampel.

\section{Sampel}

Dapat digunakan sampel serum, plasma EDTA dan heparin

Interferensi

Tidak ditemukan interferensi dengan:

$\begin{array}{ll}\text { Hemoglobin } & \leq 10 \mathrm{gr} / \mathrm{L} \\ \text { Bilirubin } & \leq 600 \mathrm{mg} / \mathrm{L} \\ \text { Trigliserida } & \leq 10 \mathrm{~g} / \mathrm{L} \\ \text { Intralipid } & \leq 5,4 \mathrm{~g} / \mathrm{L} \\ \text { Rheumatoid Faktor } & \leq 1200 \mathrm{IU} / \mathrm{mL}\end{array}$

\section{DAFTAR PUSTAKA}

1. Silbernagyl dan Lang. F, 'Ginjal, Keseimbangan Air Dan Garam', dalam Teks \& Atlas Berwarna Patofisiologi, Cetakan 1, EGC, Jakarta, 2007, 92-1332.

2. Rita C, 'Role Of Cystatine C In Kidney Function Assesment', dalam kumpulan naskah lengkap KONAS \& PIT VI PDS PATKLIN 2007, 2007, 222-25

3. Stevens LA and Levey AS, 'Measured GFR as a Confirmatory Test for Estimated GFR', in Journal of the American society of nephrology, 2009, vol 20, 2305-13

4. Lamb E, Newman DJ and Price CP, 'Kidney Function Test', inTietz Of Textbook Clinical Cemistry and Molecular Diagnosis, $4^{\text {th }}$, Saunders Elsevier, p147-Philadelpia, 2006, 797-835

5. Pardede,'Sistatin C dan hubungannya dengan Fungsi Ginjal pada Anak, dalam majalah Cermin Dunia Kedokteran, no132, 2001, 28-31 
6. Oh MS, 'Evalution Of Renal Function, Water, Electrolytes and Acid-Base Balance', In Henry's Clinical Diagnosis and Management By Laboratory Methods, 21th edition, Saunders Elsevier, Philadelpia, 2007, 147169

7. Newman DJ, 'Cystatin C', in Annals of clinical biochemistry; 2002, vol 39, 89-104.

8. Chew JSC, Saleem M, Florkowski CM and George PM, ' cystatin c a paradigm of evidence based laboratory medicine', in clin biochem rev, 2008, vol. 29, 47-62

9. Grubb A, 'Non Invasive Estimation Of GFR, The Lund Model: Simultaneous Use Cystatin C And Creatinine Based GFR -Prediction Equations, Clinical Data And An Internal Quality Check, in scandinavian journal of clinical \& laboratory investigation, 2010, vol.70, 65-70

10. Westhuyzen J, 'Review: Cystatin C: A Promising Marker And Predictor Of Impaired Renal Function', in annals if clinical \& laboratory science, 2006, vol 36, no.4, 387-94

11. Reed $\mathrm{CH}$, 'Diagnostic Aplication of Cystatin C', in British Journal of Biomedical Sciense, vol 57(4), 2000, 323-9

12. McMurray MD, Trivax JE and McCullough PA, 'Serum Cystatin C, Renal Filtration Function, and Left Ventricular Remodeling', in Cirt Heart Fail, 2009,vol.2; 86-9.

13. Filler G, Bokenkamp A, Hofmann W, Bricon TL, Martinez BC and Grubb A, 'Review Cystatin C as a Marker Of GFR - History, Indications, and Future Research', In Clinical Biochemistry , 2005, Vol 8, 1-8

14. Christensson AG, Grubb AO, Nilsson JA, Norrgren K, Sterner $G$, and Sundkvist $G$, 'Serum Cystatin C Advantagenous Compared With Serum Creatinine In The Detection Of Mild But Not Severe Diabetic Nephropathy', in journal of internal medicine, 2004,vol. 256, 510-518

15. Keevil BG, Kilpatrick ES, Nichols SP and Maylor PW, 'Biological Variation Of Cystatin C: Implications For The Assesment Of Glomerular Filtration Rate', in clinical cemistry 1998, vol.44:7, 1535-39

16. Villa $P$, Jimenez $M$, Soriano MC, Manzanares $\mathrm{J}$ and Casasnovas $\mathrm{P}$, 'Serum Cystatin $\mathrm{C}$ Concentration as a Marker of Acute Renal Dysfunction in Critically ill Patients' in critical care, 2005,vol.9 no.5, 39-43

17. Mijuskovic et al, 'Urinary Cystatin $C$ as $A$ Marker of Tubular Dysfunction', in JMB, 2007,vol.26, no.2, 98-102

18. Quantikine, 'Human Cystatin C Immunoassay, For The Quantitative Determination Of Human Cystatin Concentrations In Cell Culture Supernates, Serum, Plasma, Saliva, Urine, And Human
Milk', in catalog number DSCTCO, diunduh dari www.rndsystems.com/pdf/DSCTCO.pdf dilihat tanggal (16 desember 2011), 2010, 116

19. Buhlmann, 'Cystatin C PETIA For The Quantitative Determination Of Cystatin C In Human Serum And Plasma', in catalog number: $01-\mathrm{KK}-\mathrm{CYC}$, diunduh dari www.alpco.com dilihat tanggal (15 november 2011), 2009, 1-3

20. Dade B, 'summary of safety and effectiveness information', in catalog K003503, , diunduh dari www.fda.gov, dilihat tanggal (8 desember 2011), 2010. 